OPEN ACCESS

Edited by:

Brigitte Mauch-Mani,

Université de Neuchâtel, Switzerland

Reviewed by:

Kleber Del-Claro,

Federal University of Uberlândia, Brazil

Mary Veronica Clancy,

Université de Neuchâtel, Switzerland

*Correspondence:

Clemens Schlindwein

schlindw@gmail.com

Specialty section: This article was submitted to

Plant Microbe Interactions, a section of the journal Frontiers in Plant Science

Received: 18 October 2019

Accepted: 23 April 2020

Published: 21 May 2020

Citation: Mesquita-Neto JN, Paiva EAS, Galetto $L$ and Schlindwein C (2020)

Nectar Secretion of Floral Buds

of Tococa guianensis Mediates Interactions With Generalist Ants That

Reduce Florivory.

Front. Plant Sci. 11:627.

doi: 10.3389/fp/s.2020.00627

\section{Nectar Secretion of Floral Buds of Tococa guianensis Mediates Interactions With Generalist Ants That Reduce Florivory}

\author{
José Neiva Mesquita-Neto ${ }^{1,2}$, Elder Antônio Sousa Paiva ${ }^{1}$, Leonardo Galetto ${ }^{3}$ and \\ Clemens Schlindwein ${ }^{1 *}$
}

${ }^{1}$ Departamento de Botânica, Instituto de Ciências Biológicas, Universidade Federal de Minas Gerais, Belo Horizonte, Brazil, ${ }^{2}$ Centro de Investigación en Estudios Avanzados del Maule, Vicerrectoría de Investigación y Postgrado, Universidad Católica del Maule, Talca, Chile, ${ }^{3}$ Instituto Multidisciplinario de Biología Vegetal (UNC-CONICET), Universidad Nacional de Córdoba, Córdoba, Argentina

The specialised mutualism between Tococa guianensis and ants housed in its leaf domatia is a well-known example of myrmecophily. A pollination study on this species revealed that flowers in the bud stage exude a sugary solution that is collected by ants. Given the presence of this unexpected nectar secretion, we investigated how, where, and when floral buds of $T$. guianensis secret nectar and what function it serves. We studied a population of $T$. guianensis occurring in a swampy area in the Cerrado of Brazil by analyzing the chemical composition and secretion dynamics of the floral-bud nectar and the distribution and ultrastructure of secretory tissues. We also measured flower damage using ant-exclusion experiments. Floral bud nectar was secreted at the tip of the petals, which lack a typical glandular structure but possess distinctive mesophyll due to the presence of numerous calcium oxalate crystals. The nectar, the production of which ceased after flower opening, was composed mainly of sucrose and low amounts of glucose and fructose. Nectar was consumed by generalist ants and sporadically by stingless bees. Ant exclusion experiments resulted in significantly increased flower damage. The floral nectar of $T$. guianensis is produced during the bud stage. This bud-nectar has the extranuptial function of attracting generalist ants that reduce florivory. Pollen is the unique floral resource attracting pollinators during anthesis. Tococa guianensis, thus, establishes relationships with two functional groups of ant species: specialist ants acting against herbivory and generalist ants acting against florivory.

Keywords: plant-herbivore interactions, domatia, florivory, myrmecophily, extrafloral nectar, floral nectar, nectaries

\section{INTRODUCTION}

Nectar is a sugary secretion that mediates interactions between plants and different groups of animals (Delpino, 1886). Nectar consists predominantly of water, sugars, and a wide range of amino acids (Percival, 1961; Baker and Baker, 1973). The concentration and composition of carbohydrates and amino acids in nectar directly influence the types of visitors and their activity (Heil, 2011; Del-Claro et al., 2016). 
Nectar and nectaries can be distinguished according to their location in the plant (floral and extrafloral nectar/nectaries) and their function (nuptial and extranuptial nectaries, sensu Delpino, 1886). Floral nectar is produced and secreted by nectaries located in different floral whorls (e.g., calyx, corolla, androecium, and gynoecium) while extrafloral nectar is produced by nectaries situated outside the flower on virtually any vegetative structure (Elias, 1972; Bentley, 1977; Dalvi et al., 2017). Nectar, from a functional point of view, has two main roles: attracting pollinators or attracting defenders (Heil, 2011). Pollinators are linked to plant reproduction when collecting nectar (nuptial function), while defenders usually discourage herbivorous insects from feeding on the plant when they are patrolling plants and consuming extranuptial nectar (Delpino, 1886 apud Bentley, 1977). These conceptualizations for nectaries and nectar according to their location and function may overlap in the literature. The site of nectar secretion and its function usually coincide, with most floral nectaries presenting nuptial functions and extrafloral nectaries the extranuptial function (Feldhofen, 1933). Nevertheless, this is not a rule, and sometimes extrafloral nectaries are involved in pollination (Faegri and Van Der Pijl, 1979; Weberling, 1981), while floral nectaries may act in plant defense (Paiva, 2011 and references therein; Del-Claro et al., 2013).

Extranuptial nectar, in most cases, attracts ants, most species of which have aggressive and predatory behaviors that defend the plant against herbivores (Galetto and Bernardello, 2003; Heil, 2008, 2015; Del-Claro et al., 2016). This nectar can be a critical food resource for nectarivorous ants (Davidson, 1997; Blüthgen et al., 2000; Blüthgen and Fiedler, 2004; Schmid et al., 2010), by contributing to colony growth. For some ant species, nectar can comprise up to $90 \%$ of all the food collected (Lach et al., 2009; Byk and Del-Claro, 2011), but usually accounts for up to $10 \%$ of the food requirements of a colony (Young and Hermann, 1980; Fewell et al., 1992; Tillberg and Breed, 2004). Ants generally prefer sucrose-rich nectars (Stpiczynska, 2003; Blüthgen and Fiedler, 2004; González-Teuber and Heil, 2009; Nepi et al., 2009), but a few species are not able to digest disaccharides and prefer nectars rich in hexoses (Martínez del Rio, 1990; Heil et al., 2005).

The degree of specialization of interactions between extranuptial nectars and ants can vary widely. In generalised interactions, ants usually do not live on the plant itself, and extranuptial nectar is the only food reward produced by the plant (Galetto and Bernardello, 2003; Del-Claro et al., 2013; Marazzi et al., 2013), forcing ants to complement their nutritional requirements through other food items (Heil et al., 1998; Tillberg and Breed, 2004; Feldhaar et al., 2010; Lanan and Bronstein, 2013). In these cases, plant-ant mutualisms can be opportunistic and, as a result, the quality and quantity of defense ants provide to the plant can be variable (Ness et al., 2006; Miller, 2007; Palmer et al., 2010; Del-Claro et al., 2013). Myrmecophytic mutualisms, on the other hand, are classic examples of obligatory and specialised mutualisms (Davidson and Mckey, 1993; Heil and McKey, 2003). The involved plants maintain intimate associations with ant colonies of certain species, which are housed in specific chambers, such as stems, empty spines, or domatia (Davidson and Mckey, 1993).
Myrmecophytic plants (e.g., Acacia, Cecropia, Leonardoxa, Piper, Macaranga, and Tococa) generally provide all the nutrient needs of resident ants (Davidson and Mckey, 1993; Heil et al., 2004; Webber et al., 2007).

The myrmecophytic ant-domatia interaction of Tococa guianensis is a well-known example of obligatory and specialised mutualism (Davidson and Mckey, 1993) because the plants provide all the food needs of resident ants, and the ants protect the plant against herbivore attack (Davidson and Mckey, 1993; Heil et al., 1998). However, during a previous study on pollination and pollinators (Mesquita-Neto et al., 2018), we noted that flower buds of $T$. guianensis exude a sugary solution that attracts ants. The flowers of $T$. guianensis are visited exclusively by pollencollecting bees (Ranieri et al., 2013; Mesquita-Neto et al., 2018). Given this unexpected and unknown floral nectar secretion, we investigated how, where, and when floral buds of T. guianensis secrete nectar and what function it serves. We expected that the nectar of $T$. guianensis secreted in the bud-stage be related to the attraction of flower defenders (extranuptial function). Thus, to understand the function of this nectar secretion of floral buds, we asked the following questions: (1) What is the chemical composition of this floral bud nectar, and when is it secreted? (2) What are the secretory structures, and where are they located? (3) What are the species of visiting ants? and (4) Does the presence of visiting ants reduce flower damage?

\section{MATERIALS AND METHODS}

\section{Species and Habitat}

Tococa guianensis is a $1-5 \mathrm{~m}$-tall shrub distributed widely in the Neotropics, where it occurs from southern Mexico to Brazil (Michelangeli, 2005). The species occurs in the Cerrado in Brazil as well as other Neotropical savannahs, especially on wet soils (Michelangeli, 2003). The flowers have poricidal anthers and are pollen-only flowers, like most other species of Melastomataceae (Buchmann, 1983).

The studied population of $T$. guianensis occurs in a swampy area close to the edges of gallery forest in Parque Estadual do Rio Preto (Rio Preto Nature Reserve), located in the Espinhaço Mountain Range in the state of Minas Gerais, Brazil $\left(18^{\circ} 05^{\prime} 28.3^{\prime \prime} 2 \mathrm{~S}, 43^{\circ} 20^{\prime} 29.2^{\prime \prime} 2 \mathrm{~W}\right)$. The Park encompasses an area of about 12,000 ha, which is mainly covered with natural Cerrado vegetation (Brazilian savannah). In the study area, the shrubs flower from June to November (Ranieri et al., 2013; MesquitaNeto et al., 2018). Field experiments and observations were carried out from September to December of 2015 and 2016. The climate of the region is tropical with well-delimited dry (AprilSeptember) and rainy (October-March) seasons; the average annual temperature is $19^{\circ} \mathrm{C}$ (Salino et al., 2013).

\section{Distribution and Structure of Nectaries}

We randomly selected and bagged floral buds $(n=6)$ and open flowers $(n=7)$ with organza bags shortly before sunset $(\sim 18: 00)$ to exclude visitors and allow nectar to accumulate. The following morning, we collected the flowers at anthesis and floral buds with accumulated nectar and fixed them in Karnovsky solution, 
at $\mathrm{pH} 7.2$ with $0.1 \mathrm{M}$ phosphate buffer (Karnovsky, 1965), for $24 \mathrm{~h}$. We then dehydrated the samples in an ethanol series and embedded them in synthetic resin (2-hydroxyethyl methacrylate) (Leica ${ }^{\circledR}$ ), according to Paiva et al. (2011). To locate and analyze the anatomy of the nectar secreting structures, we obtained longitudinal and transverse sections (5 $\mu \mathrm{m}$ thick) with a Zeiss Hyrax M40 rotary microtome, stained them with toluidine blue solution at pH 7.4 (O'Brien et al., 1964), arranged them on slides and mounted them in Entellan ${ }^{\circledR}$ for study by light microscopy. We then employed histochemical tests on resin embedded sections obtained with a rotary microtome. We used lugol for the identification of starch (Johansen, 1940), 0.02\% aqueous solution of Ruthenium red for the detection of pectic compounds (Jensen, 1962), and 10\% aqueous ferric chloride solution for phenolic substances (Johansen, 1940). We obtained images using an Olympus digital camera (Olympus LC20, Münster, Germany) coupled to a light microscope (Olympus CX-41, Tokyo, Japan).

For scanning electron microscopy (SEM), we fixed floral buds using Karnovsky fixative ( $\mathrm{pH} 7.2$ in $0.1 \mathrm{M}$ phosphate buffer; modified from Karnovsky, 1965) and dehydrated them in an ethanol series as described for light microscopy. The samples were critical-point dried using liquid $\mathrm{CO}_{2}$; glued on metallic supports for frontal, ventral, and lateral views, using carbon tape; coated with gold (Robards, 1978; Sõber et al., 2010) and observed using a Quanta 200 scanning electron microscope (FEI Company, Eindhoven, Netherlands), at $12-0 \mathrm{kV}$.

\section{Transmission Electron Microscopy}

For transmission electron microscopy, we subjected fragments of the distal border ( $2 \mathrm{~mm}$ long) of petals from pre-anthesis floral buds to vacuum in Karnovsky solution at $\mathrm{pH} 7.2$ with $0.1 \mathrm{M}$ phosphate buffer (Karnovsky, 1965), fixed them for $24 \mathrm{~h}$ and post-fixed them in $1 \%$ osmium tetroxide $(0.1 \mathrm{M}$ phosphate buffer, $\mathrm{pH}$ 7.2). We then washed the samples in phosphate buffer (0.1M, pH 7.2), dehydrated them in an ethanol series, and embedded them in low-viscosity epoxy resin (Spurr, 1969). We contrasted $50 \mathrm{~nm}$ ultrathin sections with uranyl acetate and lead citrate and examined them using a Tecnai G2-12Spirit transmission electron microscope (Philips/FEI Company, Eindhoven, Netherlands) at $80 \mathrm{kV}$.

\section{Nectar Secretion Dynamics and Nectar Sugar Composition}

We marked and bagged forty floral buds of 10 individuals of T. guianensis ( $n=4$ per individual) with organza bags to prevent visitor access and to allow nectar to accumulate. The buds were randomly assigned to treatments, independently of their size or developmental stage. We collected accumulated nectar at 4-h intervals during $24 \mathrm{~h}$ (at 20:00 h, 00:00 h, 04:00 h, 08:00 h, 12:00 h, and 16:00 h). The sampling occurred in 1 day, and all the 40 buds were sampled during every interval. We collected nectar droplets with graduated glass microcapillaries and measured nectar volume $(\mu \mathrm{L})$ and sugar concentration (percentage of mass sugar/total mass solution) with a pocket refractometer (0-50\%, wt/wt; Atago, Tokyo, Japan) at every interval. We fitted penalized quasi-likelihood (PQL) generalised mixed effects models (GLMMs) with a quasi-poisson distribution to compare differences in accumulated nectar volume $(\mu \mathrm{L})$ among time intervals (fixed effect) using the function glmmPQL of the $\mathrm{R}$ package MASS. We randomly assigned plants to treatments, and so plant individual was introduced as a random effect. The volume of nectar per time interval was nested within individual plants to reflect the repeated measures of our sampling design.

To analyze sugar composition we collected accumulated drops of nectar from 10 buds of 10 random plants, which were previously bagged for at least $12 \mathrm{~h}$, with graduated glass microcapillaries. We then transferred the drops to filter paper and placed them in individual sealed-tubes containing silica gel for dehydration and to prevent oxidation (Galetto and Bernardello, 2005). The stored nectar was dissolved in distilled water before sugar composition analysis by spectrophotometry. We determined absorbance at a wavelength of $340 \mathrm{~nm}$ using a spectrophotometer (Metrolab 330, Switzerland). For quantitative analysis, we used reagent kits for glucose, fructose, and sucrose (Sigma-Aldrich Co., St. Louis, MI, United States), following the methodologies proposed by Tölke et al. (2018) and references therein. We used a linear mixed-effects model (LMM) to compare the proportions of sugars that make up the nectar samples of the floral buds of T. guianensis using the lmer function of the $\mathrm{R}$ package lme4. We used plant individual as a random effect and sugars as fixed effects.

\section{Insects Associated With Floral Bud Nectar}

Qualitative data related to floral bud nectar-exploring insects, such as species identity and behavior, were taken from field observations for two consecutive years (September to December 2015 and 2016). The collected insects are housed in the Entomological Collection of Universidade Federal de Minas Gerais (Centro de Coleções Taxonômicas da UFMG, Belo Horizonte, Brazil). To relate quantitative ant data to nectar secretion pattern during a period of 1 day, we collected all ants and other insects from the floral buds of the 10 tagged individuals of T. guianensis (10 min per plant) at regular 4 -h intervals for $24 \mathrm{~h}$ (at 20:00 h, 00:00 h, 04:00 h, 08:00 h, 12:00 h and 16:00 h). The sampling occurred over a total of $10 \mathrm{~h}(1.7 \mathrm{~h}$ per interval* 6 intervals) on 1 day. We tagged the sampled ants with the number of the individual plant and collection time. We then identified the ants to species level in the laboratory. Thus, we determined the spectrum of ant visitors, as well as their relative abundance, in floral buds throughout day and night.

\section{Ant Exclusion Experiment and Floral Damage}

We experimentally excluded ants from T. guianensis plants to compare damage to flowers of these ant-excluded plants with those of plants visited by ants (control). For the treatment group ( $n=10$ ant-excluded shrubs), we applied a sticky resin (Tanglefoot $^{\mathrm{TM}}$ ) at the base of the trunk and inflorescences to hamper the traffic of ants and other crawling insects on the plant. After the application of the resin, we scanned the surface of the shrubs and removed any remaining insects manually. We also established a control group of 10 individual plants on which ants had free access to floral buds. We assigned five inflorescences of 10 individuals to each group (treatment and control) and counted 
the total number of floral buds per inflorescence. We counted the number of intact and damaged buds or flowers after $48 \mathrm{~h}$. Floral bud damage was considered any eaten part of the corolla or holes in, or complete destruction of buds. We obtained the proportion of damaged buds as the ratio between the total initial number of buds and the number of buds damaged on each plant $48 \mathrm{~h}$ later. We used a GLMM (Gaussian distribution) to compare the proportion of florivory between control (plant individuals with ants) and treatment (ant-excluded plants) groups using the glmmPQL function of the R package MASS. Plant individual was included as a random effect.

\section{RESULTS}

\section{Floral Morphology and Nectar-Producing Tissues}

The inflorescence of T. guianensis is a cymous dichasia with short-pedicellate flowers (Figure 1A). The pentamerous corolla has light pink to white petals, which are 6-8 $\mathrm{mm}$ long, 4-5 $\mathrm{mm}$ wide, smooth and velvety. The androecium is the most prominent whorl, with 10 equally sized stamens with white $5 \mathrm{~mm}$-long anthers (Figure 1A). At the bud stage, the contorted corolla exudes a conspicuous drop of floral nectar at the tip (Figure 1B). This secretory stage extends from young buds to the beginning of anthesis, that is, a few minutes before floral opening. During the first hour of anthesis, secretion could be seen emerging from the apex of the petal (Figure 1C). Secretion ceased when the corolla fully opened; the floral lifespan lasted up to $24 \mathrm{~h}$.

We found no evidence of differentiated secreting tissue in the flowers of $T$. guianensis. At the site of nectar release, the petals showed no evidence of a conspicuous nectary, with both petal surfaces being covered by a uniform and papillose epidermis (Figures 2A,B). The mesophyll of the petals was homogeneous, composed of spongy parenchyma with globeshaped cells (Figure 2B). These cells possessed a large vacuole with phenolic substances and large calcium oxalate crystals (druses) (Figure 2B), whose density increased toward the petal apex (Figure 2C). The apical portion of the petals, corresponding to the nectar releasing area, had no special vascular system, and just some collateral vascular bundles with xylem and phloem cells (Figures 2D,E). The parenchyma cells of the mesophyll had pectin-rich primary walls with large intercellular spaces, which were mainly subepidermal and full of pectin. These pectin pockets release their contents to the outside when ruptured (Figure 2F).

The velvety appearance of the petal surface is due to short papillae-like trichomes (Figures 3A,B), which occur in high density and extend to the edges of the petal (Figures 3B,C). All of the epidermal cells, whether of ordinary cells or short trichomes, were non-glandular and had a thick wavy cuticle that makes the surface striate (Figure 3C). Small pores (about $1 \mu \mathrm{m}$ ) are spread over a thin film of cuticular waxes (Figure 3D), but do not extend across the cuticle proper. We observed a firmly adhered cuticle, in which wall elements extend into the cuticular layer toward the surface (Figures 3E,F). Both epidermal and parenchyma cells have organelle-poor cytoplasm with a large central vacuole (Figure 3G) where phenolic substances accumulated. This vacuole is very large and pushes the remaining portion of the cytoplasm against the cell wall (Figure 3G), where a few oil droplets and organelles, such as plastids (Figure $\mathbf{3 H}$ ) and mitochondria, could be observed.

\section{Nectar Properties and Production Pattern}

The nectar secreted by the floral buds of $T$. guianensis was colorless and had a viscous consistency. The sugar concentration of the nectar ranged from 15 to $20 \%$ (wt/wt). Sucrose accounted for $83-98 \%$ of the sugars in the nectar, while hexoses (glucose and fructose) made up the remaining $2-17 \%$ (Figure 4). The glucose content of the nectar samples was slightly, but not significantly, higher than that of fructose (LMM: $\chi^{2}=1237.4$, d.f. $=2, P \leq 0.001, \mathrm{AIC}=96.4$ ).

Floral buds of different sizes secreted nectar beginning in earliest bud developmental stages $(<2 \mathrm{~mm})$ until bud opening $(>9 \mathrm{~mm})$. We recorded nectar secretion in all monitored time intervals throughout the day and night (Figure 5). Only $27 \%$ of the floral buds (11) accumulated nectar in any time interval, and a given bud produced nectar only during one or two of the six fourhour intervals, with the exception of one bud (among the total number of buds labeled) that accumulated nectar in each of all sampling intervals. We noted the highest number of floral buds with accumulated nectar during early night (20-24 h; eight buds, $19.5 \%)$, while nectar accumulated in seven (17\%) buds during the evening (16-20 h) (Figure 5). The volume of nectar secreted per floral bud also varied among sampling intervals (GLMM: $\chi^{2}=16.9, P \leq 0.005$; Figure 5). There was a peak volume of accumulated nectar in the late afternoon until midnight (16-24 h; Figure 5).

\section{Insects Attracted to Flower Bud Nectar}

Nectar droplets attracted insect visitors, mainly ants and sporadically wasps and stingless bees (Figure 6). We recorded the ant species Camponotus rufipes (Fabricius), Camponotus crassus (Mayr), and Cephalotes pusillus (Klug), along with sporadic visits of Oxytrigona tataira (Smith) (Apidae, Meliponini) (Figure 6C) and an unidentified wasp. Species of the genus Camponotus were the most common ants seeking floral bud nectar. These ants exhibited aggressive behavior (attacks, approaches, and offensive tail-flips) toward other insects or animals when these approached floral buds (Figure 7B). However, these ants did not display aggressive behavior toward pollinators (we recorded 103 floral visits of 19 bee species). In contrast, C. pusillus exhibited a fugitive behavior when other insects arrived at the inflorescences. We found individuals of $C$. rufipes in floral buds during all day and night sampling intervals while those of C. crassus and C. pusillus were recorded exclusively during the day (Figure 8).

\section{Ant Exclusion Experiment}

We found visible damage to the floral buds of $T$. guianensis, which varied considerably from tiny holes or small removed petal parts, such as petal borders, to the removal of almost the entire bud (Figure 7). Plants with free access for ants to the floral 

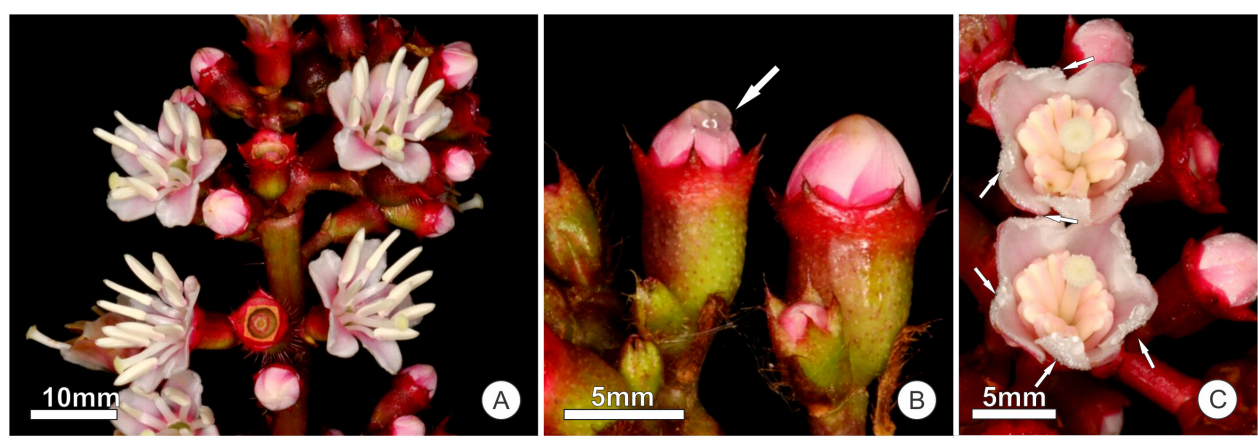

FIGURE 1 | Floral structures of Tococa guianensis. (A) Inflorescence with floral buds and flowers at anthesis; (B) Floral buds of a previously bagged inflorescence (not accessible to visitors), one with a drop of accumulated nectar (arrow); (C) Freshly opened flowers with still folded stamens of a previously bagged inflorescence showing secretion droplets at the tip of the petals (arrows).

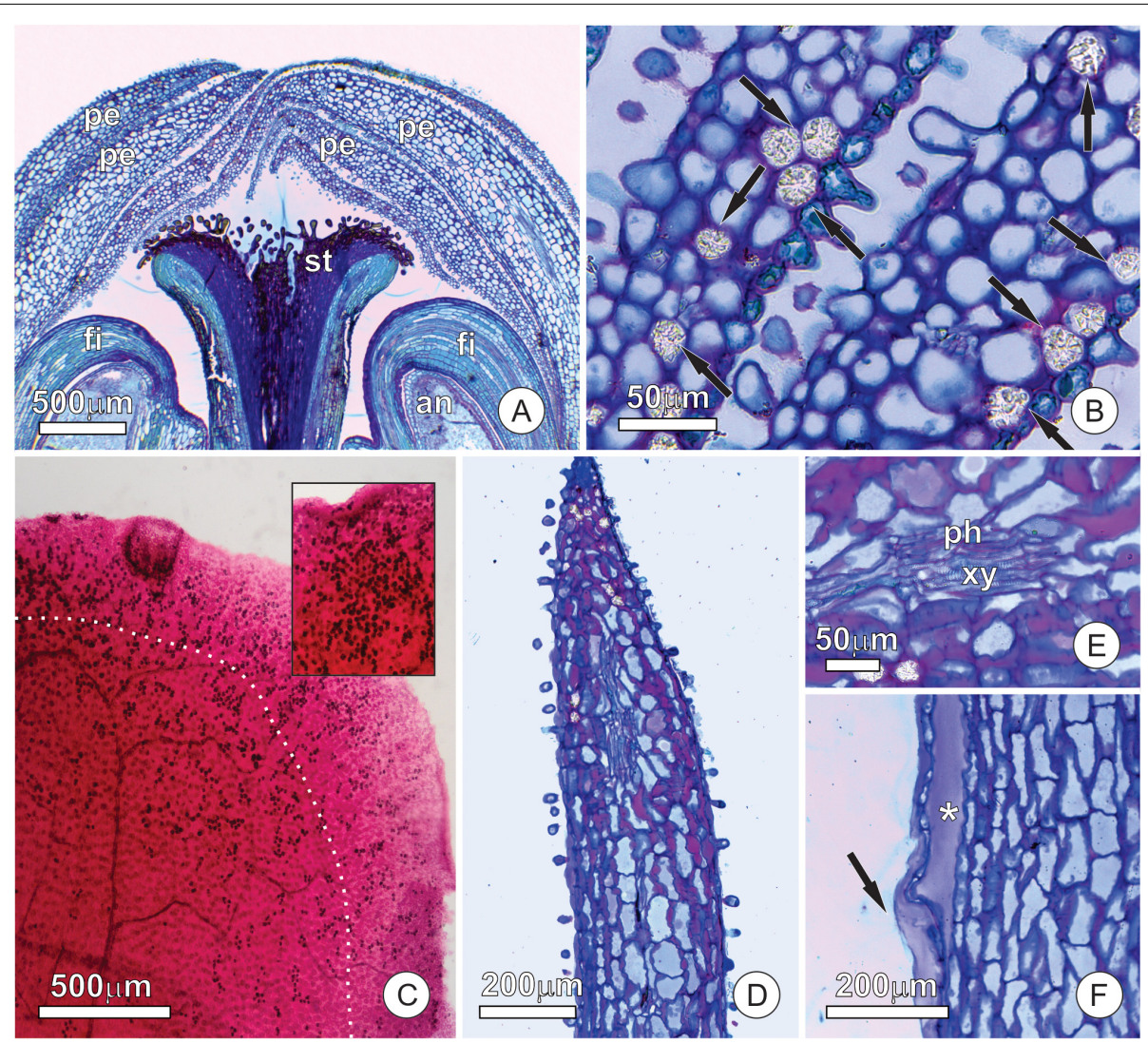

FIGURE 2 | Distribution of tissues and structures involved in nectar secretion at the apex of the floral buds of Tococa guianensis. (A,B) Uniform and papillose epidermis of adaxial and abaxial petal surfaces. (A) Apex of floral bud in longitudinal section; (B) mesophyll of petals composed of spongy parenchyma with globe-shaped cells and large vacuoles containing phenolic substances and large calcium oxalate crystals (arrows); (C) Clarified leaf stained with safranin showing calcium oxalate crystals (dark points); notice that these crystals are strongly concentrated in an area of about $0.5 \mathrm{~mm}$ wide at the border of the petal (see limit by a dotted line). The insert shows how concentrated the crystals can appear; (D-F) apical portion of a petal (E) showing thick cell walls in red due to the presence of pectin and vascular bundle with phloem and xylem cells; (F) Margin of the apical portion of the petal showing subepidermal pectin pocket ${ }^{*}$ ) with released content (arrow) (an, anther, fi, filament, pe, petal, st, stigma, ph, phloem, xy, xylem)

bud nectar (control group) had a proportion of floral damage close to zero $(0.07 \pm 0.11)$. Florivory was, on average, 15 times $(1500 \%)$ higher $\left(1.07 \pm 0.11\right.$; GLMM: $\chi^{2}=18.45$, d.f. $=1$, $P \leq 0.001$; Figure 9) in ant-excluded plants (treatment). We noted grasshoppers (adults and nymphs, Orthoptera) consuming parts of the buds of control and treated plants and larvae of Rekora cf. marius (Lycaenidae, Lepidoptera) in plants of the control group. 

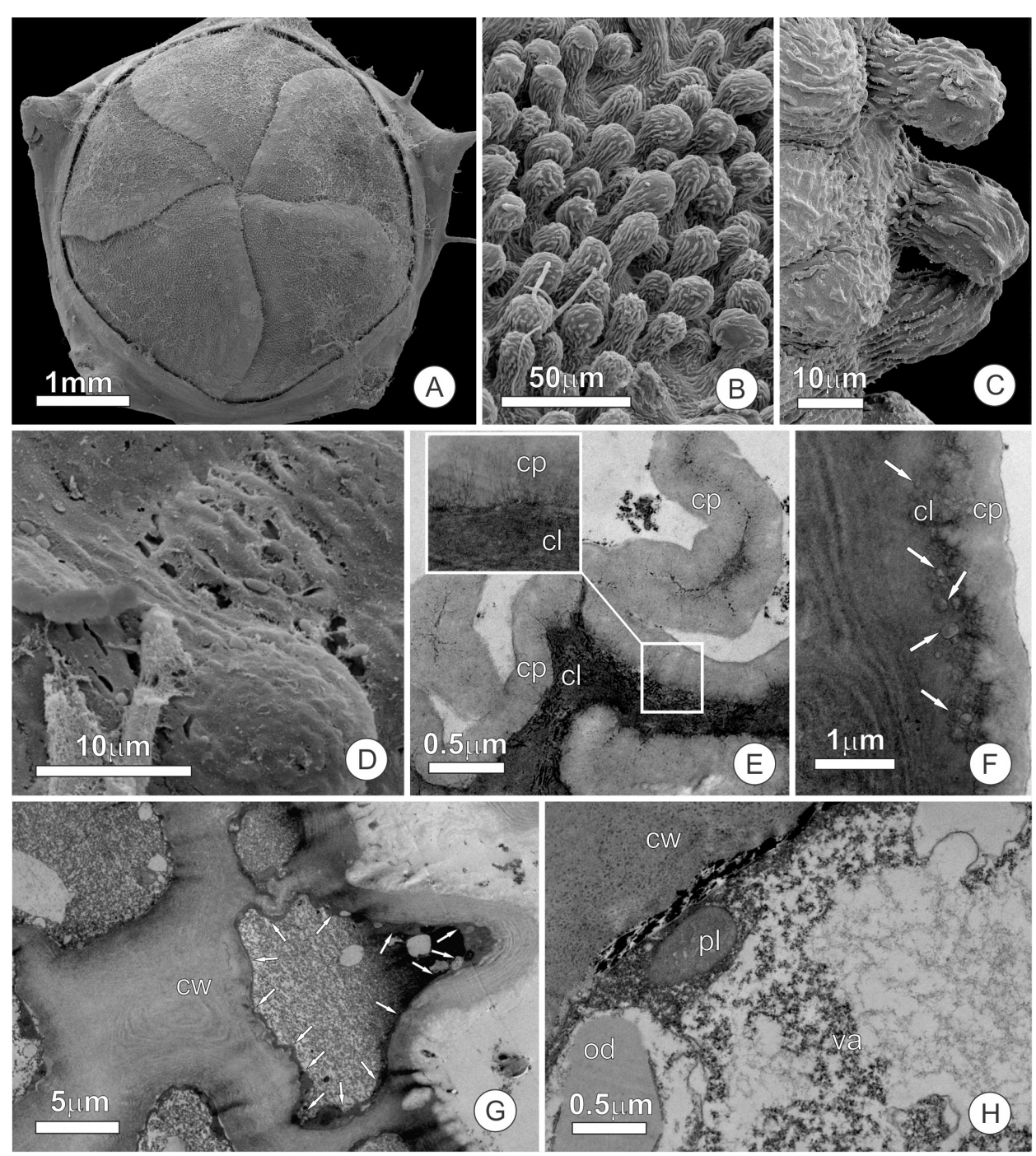

FIGURE 3 | Micromorphology and ultrastructure of the apex of petals of Tococa guianensis in bud stage. (A-D) SEM images of petal surface. (A) Entire flower bud; note the imbricated petals. (B,C) Detail of abaxial surface of petals, presenting short papillae-like trichomes. (D) Detail of cuticle surface showing small pores. (E-H) Ultrastructure of cells at the distal portion of the petals. (E,F) Detail of cuticle in striated portion; notice cell wall elements that extend into the cuticle proper [see insert on (E)]. Arrows in (F) indicate small pockets under the cuticle proper. (G,H) Cytoplasm of an epidermal (G) and a parenchyma (H) cell with a large central vacuole with phenolics and scarce organelles (cl, cuticular layer, cp, cuticle proper, cw, cell wall, od, oil droplet, pl, plastid, va, vacuole).

\section{DISCUSSION}

The present study shows that the nectar produced in floral buds of T. guianensis, before flower opening, attracts ants that protect the flowers against florivores. This nectar is not involved in pollination but rather in the attraction of flower defenders. Thus, the floral nectar has an extranuptial function because buds are visited and protected by generalist ant species commonly found on other plant species, with and without extrafloral nectaries, in the Cerrado (Belchior et al., 2016; Sendoya et al., 2016). Sucrose, which makes up the major constituent of the floral bud nectar of T. guianensis, seems to impose restrictions on domatia-nesting ants, as obligatory mutualistic ants usually lack enzymes able to digest this disaccharide (Heil et al., 2005; Kautz et al., 2009).
Therefore, according to our findings, this interaction involves mutual benefits because T. guianensis buds provide food (floral nectar) to ants, and the aggressive and predatory behavior of the ants reduce damage to the floral buds. Therefore, this plantant relationship fits the criteria to be considered a mutualism (Bronstein, 2015).

\section{How and Where Is Floral Bud Nectar Secreted?}

The nectar observed in the apical portion of the petals of T. guianensis is produced by a non-structured nectary, with no indication of cells related to its synthesis. This kind of extranuptial, non-structured floral nectary has been reported for some species of Bromeliaceae (Galetto and Bernardello, 1992). 


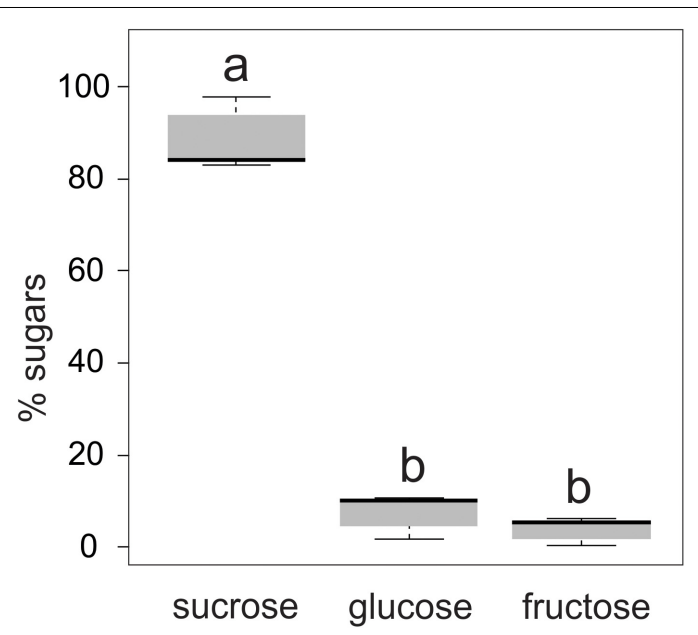

FIGURE 4 | Relative proportion of sugars present in the nectar secreted by the floral buds of Tococa guianensis ( $n=10$ floral buds, 10 plants). Different letters indicate significant differences (LMM: $\chi^{2}=1237.4$, d.f. $=2, P \leq 0.001$ ).

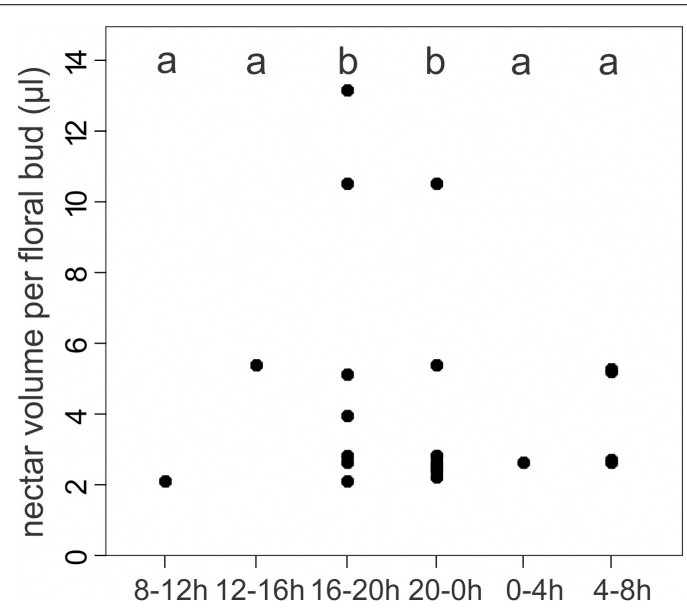

FIGURE 5 | Nectar volume of floral bud secreting nectar per time interval for 41 bagged floral buds from 10 individuals of Tococa guianensis. Nectar is secreted in all 4-h time intervals around the clock. Different letters on topside indicate significant differences in nectar secretion (GLMM: $\chi^{2}=16.9$, d.f $=5$, $P \leq 0.005$, quasi-poisson distribution). Number of floral buds secreting nectar: 8-12 h: 1 bud; $12-16$ h: 1 bud; $16-20$ h: 7 buds; 20-0 h: 8 buds; 0-4 h: 1 bud; 4-8 h: 4 buds.

The cells of the petals, both epidermal and mesophyllous, accumulate phenolic substances and are organelle-poor, with no indication of metabolism related to the secretory process. By showing nectar secretion in wounded leaves, Heil (2016) demonstrated that few structural elements are required to produce a functional nectary.

The presence of calcium oxalate crystals in structures related to nectar secretion, as observed in T. guianensis, seems to be very common, as pointed-out by Gonçalves-Souza et al. (2016). The presence of calcium crystal inclusions near the vascular system may be related to the translocation of solutes through the phloem (Metcalfe and Chalk, 1979; Paiva and Machado, 2005;

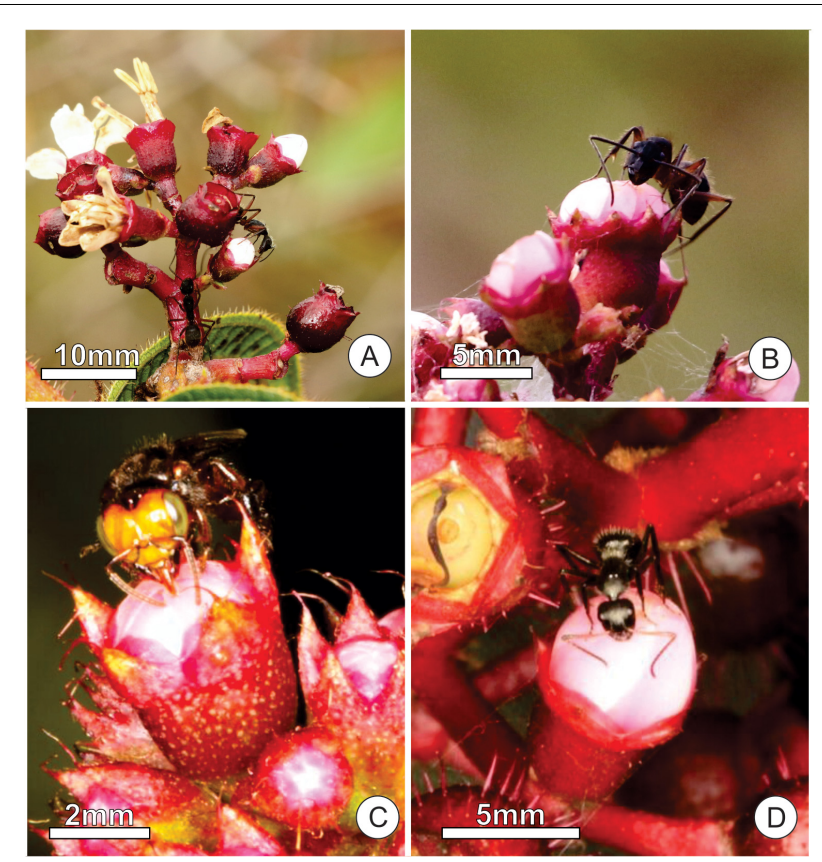

FIGURE 6 | Visitors of the floral buds of Tococa guianensis. (A,B) Camponotus rufipes; (C) Worker bee of Oxytrigona tataira; (D) Camponotus crassus.

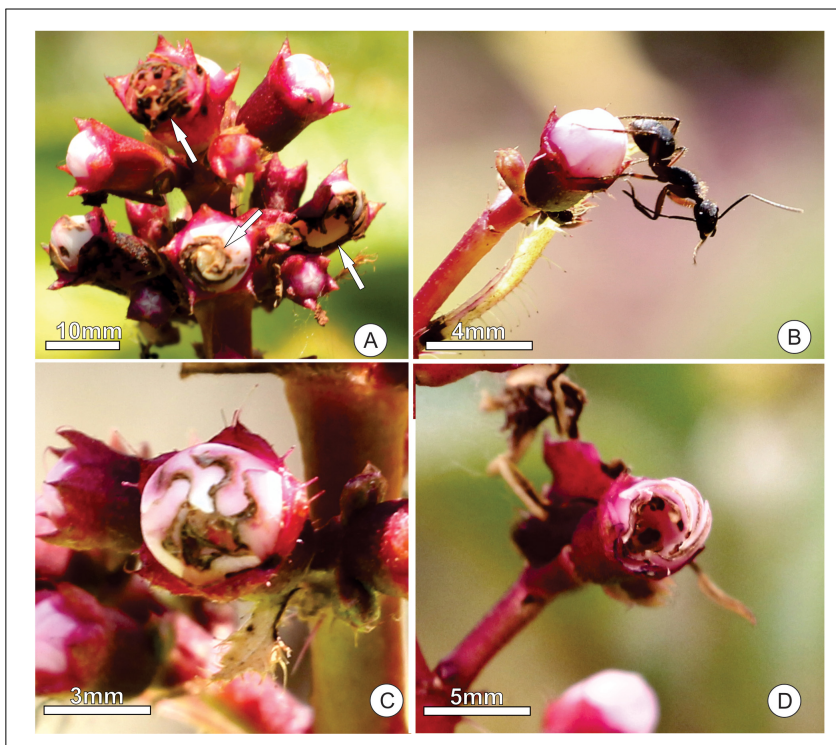

FIGURE 7 | Observed damage to the floral buds and attack behavior of ants on Tococa guianensis. (A) arrows pointing to some floral damage in buds of an inflorescence; (B) aggressive behavior (mandible opening) of Camponotus rufipes on a floral bud; (C) floral bud with petals damaged at the apical portion; (D) floral bud damaged laterally, with stamens, stigma and style removed.

Pireda et al., 2018) and seems to be important for allowing phloem transport (see Paiva, 2019 and references therein). Therefore, considering the absence of nectar secreting cells, we 


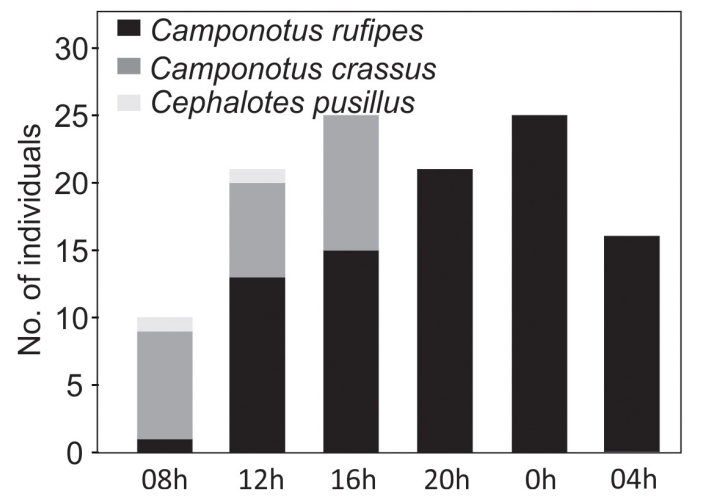

FIGURE 8 | Number of individuals of the three ant species sampled visiting the 41 focal floral buds of ten plant individuals (10 min per plant; 100 min per time interval) of Tococa guianensis to take up nectar. Camponotus rufipes was recorded in all day and night intervals, while Camponotus crassus and Cephalotes pusillus visited the floral buds exclusively during daylight hours.

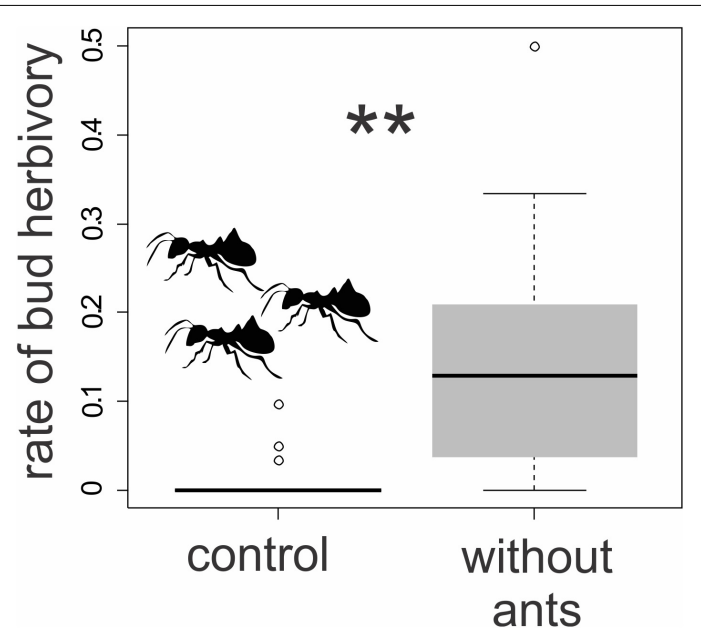

FIGURE 9 | Ant exclusion experiment of Tococa guianensis. Proportion of damaged floral buds after $48 \mathrm{~h}$ in ant-excluded plants $(n=10$ individuals; the access of ants was prevented by the application of sticky resin at the base of the trunk) and in control plants with free access for ants ( $n=10$ individuals). ${ }^{* *}$ Indicates statistical significance $\left(\chi^{2}=18.45\right.$, d.f. $=1, P \leq 0.001$, GLMM, gaussian distribution).

hypothesize that phloem is the main source of the sucrose in flower bud nectar of T. guianensis.

Although some ruptures were observed on the cuticle surface, they were superficial and did not constitute channels. Consequently, they do not allow nectar release. Considering the absence of stomata or evidence of cuticle rupture as alternatives for the release of nectar, hydrophilic channels in the cuticle could function in nectar release. Hydrophilic bridges formed by wall elements and pectin appear to be nectar release routes, allowing passage through the cuticle, as pointed-out by Paiva (2017). Similar hydrophilic pathways crossing the cuticle have been described for stomata-free floral nectaries in Orchidaceae (Stpiczynska, 2003) and other plant families
(Antón and Kamińska, 2015; Weryszko-Chmielewska and Chwil, 2016). Considering this hypothesis, nectar flow must be slow and continuous toward the petal surface because it needs to pass through countless ramifications of hydrophilic projections within the cuticular layer (Paiva, 2017). However, the nectar flow observed in T. guianensis is intense at certain moments, which makes the hypothesis of nectar release by epidermal ruptures quite probable. Such ruptures are caused by the accumulation of pectin in subepidermal pockets. The high viscosity of the nectar of T. guianensis seems consistent with this hypothesis since the sugar concentration of bud nectar was rather low and polysaccharides and nectar are released through the same rupture, mixing highly hydrophilic pectins with sugars. Thus, we consider that the high viscosity of the nectar is a consequence of the high concentration of pectins, not of sugars.

\section{What Is the Function of Nectar in the Bud-Stage?}

Nectar secreted in flowers usually functions as a reward for pollinators (De la Barrera and Nobel, 2004; Brandenburg et al., 2009). Exceptions include floral nectaries that may play a role in attracting florivores, including ants, keeping them away from structures that are important for reproduction (Del-Claro et al., 2016; Zhu et al., 2017; Villamil et al., 2019). Our results demonstrate that ant attraction by floral bud nectar reduces florivory in T. guianensis, which corresponds to an extranuptial function because the floral nectar does not attract pollinators. After the unfolding of petals, the flowers are nectarless, and ants were not attracted to reproductive structures after the bud-stage.

\section{What Is the Chemical Composition of the Floral Bud Nectar?}

Almost all the sugar that makes up the nectar of floral buds of T. guianensis is sucrose, a disaccharide predominant in phloem sap (Hall and Baker, 1972; Hayashi and Chino, 1990; De la Barrera and Nobel, 2004). The presence of fructose, glucose and other hexoses in nectar is the result of the activity of invertase enzymes that degrade sucrose from phloem sap into monosaccharides (Pate et al., 1985; Heil et al., 2005). Therefore, the predominance of sucrose over hexoses in the floral bud nectar of T. guianensis must be related to the origin of the phloem sap, with little participation of invertases.

\section{Tococa guianensis-Ant Interactions}

In the present study, the floral buds of $T$. guianensis were not commonly visited by myrmecophytic ants, which usually nest in domatia (Allomerus, Azteca, and Crematogaster, Bizerril and Vieira, 2002; Michelangeli, 2003). The sucrose-rich nectar of the floral buds of $T$. guianensis is less attractive for some myrmecophytic ants since these ant species lack the invertases required to digest this disaccharide (Heil et al., 2005; Kautz et al., 2009; but see Galetto and Bernardello, 1992 and reference therein). Generalist ant species, however, are commonly equipped with this enzyme in their digestive tracts and have a strong preference for sucrose-rich nectars (Cornelius et al., 1996; 
Stapel et al., 1997; Boevé and Wäckers, 2003; Blüthgen and Fiedler, 2004; Nepi and Stpiczyńska, 2008; González-Teuber and Heil, 2009; Nepi et al., 2009). Camponotus rufipes and C. crassus, the most common ant species on the floral buds of T. guianensis, are also commonly found on other plant species in the Cerrado (Oliveira and Brandâo, 1991; Lange et al., 2013; Dáttilo et al., 2014; Ronque et al., 2018). None of the species of the genus Camponotus are known to be associated with any obligatory mutualism (Belchior et al., 2016; Del-Claro et al., 2016; Sendoya et al., 2016). While C. rufipes forages during both day and night, C. crassus is restricted to diurnal foraging on other plant species of the Cerrado (Oliveira and Pie, 1998; Cogni et al., 2000; Tavares et al., 2008; Stefani et al., 2015), as observed for floral buds of T. guianensis. The richness of sucrose in the floral bud nectar might explain why the domatia-nesting ants of T. guianensis avoid this nectar.

Although the symbiotic interaction between ants and the foliar domatia of species of Tococa has been well studied (e.g., Cabrera and Jaffé, 1994; Alvarez et al., 2001; Dejean et al., 2006; Moraes and Vasconcelos, 2009; Michelangeli, 2010), the interaction between ants and floral bud nectar in this genus was previously unknown. While specialist ants house their colonies in leaf domatia and protect the plant against nonfloral herbivores, generalist ants have their colonies elsewhere (Yamamoto and Del-Claro, 2008; Weidenmüller et al., 2009; Belchior et al., 2016) and protect the plant against florivory (herbivores specialised on flowers). Here, we clarify the basic aspects of the biology of this new ant-Tococa interaction. Based on our findings, several new questions arise. Since T. guianensis has a wide area of occurrence, from southern Mexico to Brazil (Michelangeli, 2005), it would be interesting to survey whether (and which) other generalist ant species are involved in this type of relationship and whether there is variation in the pattern of nectar secretion among other populations. Also, do the generalist and aggressive ant species of Camponotus (Anjos et al., 2017) provide better protection against florivores than obligatory mutualistic ants? Furthermore, we expect that other species of the genus Tococa also maintain associations with flower defending ants because the rather inconspicuous, and thus far unknown, nectar droplets of the flower buds have probably been overlooked. Thus, this pattern of two different functional associations between ants and plants could be widespread.

We conclude that the nectar produced in the floral buds of T. guianensis mediates interactions with defenders. This nectar, secreted by unstructured tissue on the apical portion of the petals, is consumed by ants, which, in turn, contribute to reducing

\section{REFERENCES}

Alvarez, G., Armbrecht, I., Jiménez, E., Armbrecht, H., and Ulloa-Chacón, P. (2001). Ant-plant association in two tococa species from a primary rain forest of Colombian Choco (Hymenoptera: Formicidae). Sociobiology 38, 585-602.

Anjos, D. V., Caserio, B., Rezende, F. T., Ribeiro, S. P., Del-Claro, K., and Fagundes, R. (2017). Extrafloral nectaries and interspecific aggressiveness regulate day/night turnover of ant species foraging for nectar on Bionia coriacea. Aust. Ecol. 42, 317-328. doi: 10.1111/aec.12446 florivory. After flower opening, the production of nectar ceases, and floral visitors collect only pollen (Ranieri et al., 2013; Mesquita-Neto et al., 2018). Thus, this floral nectar, secreted at bud-stage, is not directly involved in floral resource production to pollinators but attracts generalist ants that reduce florivory.

\section{DATA AVAILABILITY STATEMENT}

The datasets generated for this study can be found in the Figshare repository doi: 10.3389/fpls.2020.00627.

\section{AUTHOR CONTRIBUTIONS}

JM-N, EP, and CS conceived the ideas and designed the methodology. JM-N, EP, LG, and CS collected the data. JM-N, LG, and EP analyzed the data. JM-N and CS led the writing of the manuscript. All authors contributed critically to the drafts and gave final approval for publication.

\section{FUNDING}

This work was supported by the Fundação de Amparo à Pesquisa do Estado de Minas Gerais (APQ-01707-14), Coordenação de Aperfeiçoamento de Pessoal de Nível Superior (Scholarship to JM-N), Conselho Nacional de Desenvolvimento Científico e Tecnológico (Scholarship to JM-N; research grants for EP and to CS Nos. 305638/2018-1 and 311935/2018-4, respectively), and the Rufford Small Grants Foundation (No. 17393-1). LG thanks Consejo Nacional de Investigaciones Científicas y Técnicas, Fondo para la Investigación Científica y Tecnológica, and Secretaría de Ciencia y Tecnología for financial support.

\section{ACKNOWLEDGMENTS}

We thank the staff of Parque Estadual do Rio Preto for assistance during fieldwork, Rosana Romero, Universidade Federal de Uberlândia, for identifying the plant species and Universidad Católica del Maule for granting the Open-Access of this article. Ultrastructural analyses were performed by the Center of Microscopy, Universidade Federal de Minas Gerais. Collecting licenses were granted by Instituto Chico Mendes de Conservação da Biodiversidade and Instituto Estadual de Florestas de Minas Gerais (No. 120/2014). 
Bentley, B. L. (1977). The protective function of ants visiting the extrafloral nectaries of Bixa orellana (Bixaceae). J. Ecol. 65, 27-38. doi: 10.2307/2259060

Bizerril, M. X., and Vieira, E. M. (2002). Azteca ants as antiherbivore agents of tococa formicaria (Melastomataceae) in Brazilian Cerrado. Stud. Neotrop. Fauna Environ. 37, 145-149. doi: 10.1076/snfe.37.2.145.8585

Blüthgen, N., and Fiedler, K. (2004). Preferences for sugars and amino acids and their conditionality in a diverse nectar-feeding ant community. J. Anim. Ecol. 73, 155-166. doi: 10.1111/j.1365-2656.2004.00789.x

Blüthgen, N., Verhaagh, M., Goitía, W., Jaffé, K., Morawetz, W., and Barthlott, W. (2000). How plants shape the ant community in the Amazonian rainforest canopy: the key role of extrafloral nectaries and homopteran honeydew. Oecologia 125, 229-240. doi: 10.1007/s004420000449

Boevé, J. L., and Wäckers, F. L. (2003). Gustatory perception and metabolic utilization of sugars by Myrmica rubra ant workers. Oecologia 136, 508-514. doi: 10.1007/s00442-003-1249-9

Brandenburg, A., Dell'Olivo, A., Bshary, R., and Kuhlemeier, C. (2009). The sweetest thing: advances in nectar research. Curr. Opin. Plant Biol. 12, 486-490. doi: 10.1016/j.pbi.2009.04.002

Bronstein, J. L. (2015). Mutualism. Oxford: Oxford University Press, doi: 10.1093/ acprof:oso/9780199675654.001.0001

Buchmann, S. L. (1983). "Buzz pollination in angiosperms," in Handbook of Experimental Pollination Biology, eds C. E. Jones, and R. J. Little (New York, NY: Van Nostrand Reinhold Company), 63-113.

Byk, J., and Del-Claro, K. (2011). Ant-plant interaction in the Neotropical savanna: direct beneficial effects of extrafloral nectar on ant colony fitness. Populat. Ecol. 53, 327-332. doi: 10.1007/s10144-010-0240-7

Cabrera, M., and Jaffé, K. (1994). A trophic mutualism between the myrmecophytic melastomataceae tococa guianensis Aublet and an Azteca ant species. Ecotropicos 7, 1-10.

Cogni, R., Raimundo, R. L. G., and Freitas, A. V. L. (2000). Daily activity of ants associated with the extrafloral nectaries of Turnera ulmifolia L. (Turneraceae) in a suburban area in Southeast Brazil. Entomol. Monthly Mag. 136, 141-147.

Cornelius, M. L., Grace, J. K., and Yates, J. R. (1996). Acceptability of different sugars and oils to three tropical ant species (Hymen., Formicidae). Anzeiger Schädlingskunde Pflanzenschutz Umweltschutz 69, 41-43. doi: 10. $1007 / \mathrm{bf} 01907668$

Dalvi, V. C., Meira, R. M. S. A., and Azevedo, A. A. (2017). Are stem nectaries common in Gentianaceae Juss? Acta Botan. Brasil. 31, 403-410. doi: 10.1590/ 0102-33062016abb0404

Dáttilo, W., Fagundes, R., Gurka, C. A., Silva, M. S., Vieira, M. C., Izzo, T. J., et al. (2014). Individual-based ant-plant networks: diurnal-nocturnal structure and species-area relationship. PLOS ONE 9:e99838. doi: 10.1371/journal.pone. 0099838

Davidson, D. W. (1997). The role of resource imbalances in the evolutionary ecology of tropical arboreal ants. Biol. J. Linnean Soc. 61, 153-181. doi: 10.1006/ bijl.1996.0128

Davidson, D. W., and Mckey, D. (1993). Ant-plant symbioses: stalking the chuyachaqui. Trends Ecol. Evol. 8, 326-332. doi: 10.1016/0169-5347(93)90240-p

De la Barrera, E., and Nobel, P. S. (2004). Nectar: properties, floral aspects, and speculations on origin. Trends Plant Sci. 9, 65-69. doi: 10.1016/j.tplants.2003. 12.003

Dejean, A., Delabie, J. H., Cerdan, P., Gibernau, M., and Corbara, B. (2006). Are myrmecophytes always better protected against herbivores than other plants? Biol. J. Linnean Soc. 89, 91-98. doi: 10.1111/j.1095-8312.2006.00660.x

Del-Claro, K., Guillermo-Ferreira, R., Zardini, H., Almeida, E. M., and TorezanSilingardi, H. M. (2013). Ants visiting the post-floral secretions of pericarpial nectaries in Palicourea rigida (Rubiaceae) provide protection against leaf herbivores but not against seed parasites. Sociobiology 60, 217-221. doi: 10. 13102/sociobiology.v60i3.217-221

Del-Claro, K., Rico-Gray, V., Torezan-Silingardi, H. M., Alves-Silva, E., Fagundes, R., Lange, D., et al. (2016). Loss and gains in ant-plant interactions mediated by extrafloral nectar: fidelity, cheats, and lies. Insectes Soc. 63, 207-221. doi: 10.1007/s00040-016-0466-2

Delpino, F. (1886). Funzione mirmecofila nel Regno vegetale. Mem. Reale Accad. Scienze Istit. Bol. Ser. IV 7, 215-323.

Elias, T. S. (1972). Morphology and anatomy of foliar nectaries of Pithecellobium macradenium (Leguminosae). Bot. Gazette 133, 38-42. doi: 10.1086/336611
Faegri, K., and Van Der Pijl, L. (1979). The Principles of Pollination Ecology. Oxford: Oxford University Press.

Feldhaar, H., Gebauer, G., and Blüthgen, N. (2010). Stable isotopes: past and future in exposing secrets of ant nutrition (Hymenoptera: Formicidae). Myrmecol. News 13, 3-13.

Feldhofen, E. (1933). Beitraege zur physiologischen anatomie der nuptialen nektarien aus den reihen der dikotylen. Beihefte Botanischen Centralblatt. Zweite Abteilung 50, 459-643.

Fewell, J. H., Harrison, J. F., Stiller, T. M., and Breed, M. D. (1992). Distance effects on resource profitability and recruitment in the giant tropical ant, Paraponera clavata. Oecologia 92, 542-547. doi: 10.1007/bf00317846

Galetto, L., and Bernardello, G. (1992). Extrafloral nectaries to attract ants in Bromeliaceae: structure and nectar composition. Can. J. Bot. 70, 1101-1106. doi: 10.1139/b92-136

Galetto, L., and Bernardello, G. (2003). Nectar sugar composition in angiosperms from Chaco and Patagonia (Argentina): an animal visitor's matter? Plant Systemat. Evol. 238, 69-86. doi: 10.1007/s00606-002-0269-y

Galetto, L., and Bernardello, G. (2005). "Rewards in flowers: nectar," in Practical Pollination Biology, eds A. Dafni, P. G. Kevan, and B. C. Husband (Cambridge: Enviroquest Ltd), 261-313.

Gonçalves-Souza, P., Gonçalves, E. G., and Paiva, E. A. S. (2016). Extrafloral nectaries in Philodendron (Araceae): distribution and structure. Bot. J. Linnean Soc. 180, 229-240. doi: 10.1111/boj.12366

González-Teuber, M., and Heil, M. (2009). Nectar chemistry is tailored for both attraction of mutualists and protection from exploiters. Plant Signal. Behav. 4, 809-813. doi: 10.4161/psb.4.9.9393

Hall, S. M., and Baker, D. A. (1972). The chemical composition of ricinus phloem exudate. Planta 106, 131-140. doi: 10.1007/bf00383992

Hayashi, H., and Chino, M. (1990). Chemical composition of phloem sap from the uppermost internode of the rice plant. Plant Cell Physiol. 31, 247-251. doi: 10.1093/oxfordjournals.pcp.a077899

Heil, M. (2008). Indirect defence via tritrophic interactions. New Phytol. 178, 41-61. doi: 10.1111/j.1469-8137.2007.02330.x

Heil, M. (2011). Nectar: generation, regulation and ecological functions. Trends Plant Sci. 16, 191-200. doi: 10.1016/j.tplants.2011.01.003

Heil, M. (2015). Extrafloral nectar at the plant-insect interface: a spotlight on chemical ecology, phenotypic plasticity, and food webs. Annu. Rev. Entomol. 60, 213-232. doi: 10.1146/annurev-ento-010814-020753

Heil, M. (2016). Nightshade wound secretion: the world's simplest extrafloral nectar? Trends Plant Sci. 21, 637-638. doi: 10.1016/j.tplants.2016.06.004

Heil, M., Fiala, B., Kaiser, W., and Linsenmair, K. E. (1998). Chemical contents of Macaranga food bodies: adaptations to their role in ant attraction and nutrition. Funct. Ecol. 12, 117-122. doi: 10.1046/j.1365-2435.1998.00158.x

Heil, M., Greiner, S., Meimberg, H., Krüger, R., Noyer, J. L., Heubl, G., et al. (2004). Evolutionary change from induced to constitutive expression of an indirect plant resistance. Nature 430:205. doi: 10.1038/nature02703

Heil, M., and McKey, D. (2003). Protective ant-plant interactions as model systems in ecological and evolutionary research. Annu. Rev. Ecol. Evol. Systemat. 34, 425-553. doi: 10.1146/annurev.ecolsys.34.011802.132410

Heil, M., Rattke, J., and Boland, W. (2005). Postsecretory hydrolysis of nectar sucrose and specialization in ant/plant mutualism. Science 308, 560-563. doi: $10.1126 /$ science. 1107536

Jensen, W. A. (1962). Botanical Histochemistry: Principles and Practice. San Francisco, CA: W. H. Freeman.

Johansen, D. A. (1940). Plant Microtechnique. New York. NY: McGraw-Hill Book Company, Inc.

Karnovsky, M. J. (1965). A formaldehyde glutaraldchydc fixative of high osmolality for use in electron microscopy. J. Cell Biol. 27, 137-138.

Kautz, S., Lumbsch, H. T., Ward, P. S., and Heil, M. (2009). How to prevent cheating: a digestive specialization ties mutualistic plant-ants to their ant-plant partners. Evolution 63, 839-853. doi: 10.1111/j.1558-5646.2008.00594.x

Lach, L., Hobbs, R. J., and Majer, J. D. (2009). Herbivory-induced extrafloral nectar increases native and invasive ant worker survival. Populat. Ecol. 51, 237-243. doi: 10.1007/s10144-008-0132-2

Lanan, M. C., and Bronstein, J. L. (2013). An ant's-eye view of an ant-plant protection mutualism. Oecologia 172, 779-790. doi: 10.1007/s00442-012-2 528-0 
Lange, D., Dáttilo, W., and Del-Claro, K. (2013). Influence of extrafloral nectary phenology on ant-plant mutualistic networks in a Neotropical savanna. Ecol. Entomol. 38. 1-7. doi: 10.1111/een.12036

Marazzi, B., Bronstein, J. L., and Koptur, S. (2013). The diversity, ecology and evolution of extrafloral nectaries: current perspectives and future challenges. Ann. Bot. 111, 1243-1250. doi: 10.1093/aob/mct109

Martínez del Rio, C. (1990). Dietary, phylogenetic, and ecological correlates of intestinal sucrase and maltase activity in birds. Physiol. Zool. 63, 987-1011. doi: 10.1086/physzool.63.5.30152625

Mesquita-Neto, J. N., Blüthgen, N., and Schlindwein, C. (2018). Flowers with poricidal anthers and their complex interaction networks- Disentangling legitimate pollinators and illegitimate visitors. Funct. Ecol. 32, 2321-2332. doi: 10.1111/1365-2435.13204

Metcalfe, C. R., and Chalk, L. (1979). Anatomy of the Dicotyledons. New York, NY: Oxford University Press, doi: 10.1163/22941932-90001102

Michelangeli, F. A. (2003). Ant protection against herbivory in three species of tococa (Melastomataceae) occupying different environments. Biotropica 35, 181-188. doi: 10.1646/01509

Michelangeli, F. A. (2005). Tococa (Melastomataceae). Flora Neotrop. 98, 1-114.

Michelangeli, F. A. (2010). Neotropical myrmecophilous Melastomataceae: an annotated list and key. Proc. Calif. Acad. Sci. 61, 409-449.

Miller, T. E. X. (2007). Does having multiple partners weaken the benefits of facultative mutualism? A test with cacti and cactus-tending ants. Oikos 116, 500-512. doi: 10.1111/j.2007.0030-1299.15317.x

Moraes, S. C., and Vasconcelos, H. L. (2009). Long-term persistence of a Neotropical ant-plant population in the absence of obligate plant-ants. Ecology 90, 2375-2383. doi: 10.1890/08-1274.1

Nepi, M., and Stpiczyńska, M. (2008). The complexity of nectar: secretion and resorption dynamically regulate nectar features. Naturwissenschaften 95:177. doi: 10.1007/s00114-007-0307-2

Nepi, M., Von Aderkas, P., Wagner, R., Mugnaini, S., Coulter, A., and Pacini, E. (2009). Nectar and pollination drops: how different are they? Ann. Bot. 104, 205-219. doi: 10.1093/aob/mcp124

Ness, J. H., Morris, W. F., and Bronstein, J. L. (2006). Integrating quality and quantity of mutualistic service to contrast ant species protecting Ferocactus wislizeni. Ecology 87, 912-921. doi: 10.1890/0012-9658(2006)87[912:iqaqom]2. $0 . \mathrm{co} ; 2$

O'Brien, T. P., Feder, N., and McCully, M. E. (1964). Polychromatic staining of plant cell walls by toluidine blue O. Protoplasma 59, 368-373. doi: 10.1007/ bf01248568

Oliveira, P. S., and Brandâo, C. R. F. (1991). "The ant community associated with extrafloral nectaries in the Brasilian cerrados," in Ant-Plant Interactions, eds C. R. Huxley, and D. F. Cutler (Oxford: Oxford University Press), 182-212.

Oliveira, P. S., and Pie, M. R. (1998). Interaction between ants and plants bearing extrafloral nectaries in cerrado vegetation. Anais Soc. Entomol. Brasil 27, 161176. doi: 10.1590/s0301-80591998000200001

Paiva, E. A. S. (2011). Petaline nectaries in Swietenia macrophylla (Meliaceae): distribution and structural aspects. Flora 206, 484-490. doi: 10.1016/j.flora. 2010.09.009

Paiva, E. A. S. (2017). How does the nectar of stomata-free nectaries cross the cuticle? Acta Botan. Brasil. 31, 525-530. doi: 10.1590/0102-33062016abb0444

Paiva, E. A. S. (2019). Are calcium oxalate crystals a dynamic calcium store in plants? New Phytol. 223, 1707-1711. doi: 10.1111/nph.15912

Paiva, E. A. S., and Machado, S. R. (2005). Role of intermediary cells in Peltodon radicans (Lamiaceae) in the transfer of calcium and formation of calcium oxalate crystals. Braz. Arch. Biol. Technol. 48, 147-153. doi: 10.1590/s151689132005000100019

Paiva, E. A. S., Pinho, S. Z., and Oliveira, D. M. T. (2011). "Large plant samples: how to process for GMA embedding?," in Light Microscopy, eds H. Chiarini-Garcia, and R. Melo (Totowa: Humana Press), 37-49. doi: 10.1007/978-1-60761-950$5 \_3$

Palmer, T. M., Doak, D. F., Stanton, M. L., Bronstein, J. L., Kiers, E. T., Young, T. P., et al. (2010). Synergy of multiple partners, including freeloaders, increases host fitness in a multispecies mutualism. Proc. Natl. Acad. Sci. U.S.A. 107, 17234-17239. doi: 10.1073/pnas.1006872107

Pate, J. S., Peoples, M. B., Storer, P. J., and Atkins, C. A. (1985). The extrafloral nectaries of cowpea (Vigna unguiculata (L.) Walp.) II. Nectar composition, origin of nectar solutes, and nectary functioning. Planta 166, 28-38. doi: 10. 1007/bf00397382
Percival, M. S. (1961). Types of nectar in angiosperms. New Phytol. 60, 235-281. doi: 10.1111/j.1469-8137.1961.tb06255.x

Pireda, S., Miguel, E. C., Xavier, V., and Da-Cunha, M. (2018). Morpho-anatomical and ultrastructural analysis of extrafloral nectaries in Inga edulis (Vell.) Mart. (Leguminosae). Nordic J. Bot. 36, e01665. doi: 10.1111/njb.01665

Ranieri, B. D., Silveira, F. A. O., and Franceschinelli, E. V. (2013). Biologia floral e comportamento de polinizadores de tococa guianensis Aubl. (Melastomataceae). Lundiana 11, 3-8.

Robards, A. W. (1978). "An introduction to techniques for scanning electron microscopy of plant cells," in Electron Microscopy and Cytochemistry of Plant Cells, ed. J. L. Hall (New York, NY: Elsevier), 348-403.

Ronque, M. U., Fourcassié, V., and Oliveira, P. S. (2018). Ecology and field biology of two dominant Camponotus ants (Hymenoptera: Formicidae) in the Brazilian savannah. J. Nat. History 52, 237-252. doi: 10.1080/00222933.2017.1420833

Salino, A., Mota, N. F. D. O., and Almeida, T. E. (2013). Lycophytes and monilophytes in rio preto state park, minas gerais, Brazil. Acta Botan. Brasil. 27, 252-263. doi: 10.1590/s0102-33062013000200002

Schmid, V. S., Schmid, S., Steiner, J., and Zillikens, A. (2010). High diversity of ants foraging on extrafloral nectar of bromeliads in the Atlantic rainforest of southern Brazil. Stud. Neotrop. Fauna Environ. 45, 39-53. doi: 10.1080/ 01650521003647647

Sendoya, S. F., Blüthgen, N., Tamashiro, J. Y., Fernandez, F., and Oliveira, P. S. (2016). Foliage-dwelling ants in a neotropical savanna: effects of plant and insect exudates on ant communities. Arthropod-Plant Interact. 10, 183-195. doi: 10.1007/s11829-016-9423-2

Sõber, V., Moora, M., and Teder, T. (2010). Florivores decrease pollinator visitation in a self-incompatible plant. Basic Appl. Ecol. 11, 669-675. doi: 10.1016/j.baae. 2010.09 .006

Spurr, A. R. (1969). A low-viscosity epoxy resin embedding medium for electron microscopy. J. Ultrastruct. Res. 26, 31-43. doi: 10.1016/s0022-5320(69)90033-1

Stapel, J. O., Cortesero, A. M., De Moraes, C. M., Tumlinson, J. H., and Joe Lewis, W. (1997). Extrafloral nectar, honeydew, and sucrose effects on searching behavior and efficiency of Microplitis croceipes (Hymenoptera: Braconidae) in cotton. Environ. Entomol. 26, 617-623. doi: 10.1093/ee/26.3.617

Stefani, V., Pires, T. L., Torezan-Silingardi, H. M., and Del-Claro, K. (2015). Beneficial effects of ants and spiders on the reproductive value of Eriotheca gracilipes (Malvaceae) in a tropical savanna. PLOS ONE 10:e131843. doi: 10. 1371/journal.pone.0131843

Stpiczynska, M. (2003). Nectar resorption in the spur of Platanthera chlorantha Custer (Rchb.) Orchidaceae - structural and microautoradiographic study. Plant Systemat. Evol. 238, 119-126. doi: 10.1007/s00606-0020281-2

Tavares, A. A., Bispo, P. C., and Zanzini, A. C. (2008). Effect of collect time on communities of epigaeic ants (Hymenoptera: Formicidae) in areas of Eucalyptus cloeziana and cerrado. Neotrop. Entomol. 37, 126-130. doi: 10.1590/ s1519-566x2008000200003

Tillberg, C. V., and Breed, M. D. (2004). Placing an omnivore in a complex food web: dietary contributions to adult biomass of an ant. Biotropica 36, 266-271. doi: 10.1111/j.1744-7429.2004.tb00318.x

Tölke, E. D., Bachelier, J. B., Lima, E. A., Galetto, L., Demarco, D., and CarmelloGuerreiro, S. M. (2018). Diversity of floral nectary secretions and structure, and implications for their evolution in Anacardiaceae. Bot. J. Linnean Soc. 187, 209-231. doi: 10.1093/botlinnean/boy016

Villamil, N., Boege, K., and Stone, G. N. (2019). Testing the distraction hypothesis: do extrafloral nectaries reduce ant-pollinator conflict? J. Ecol. 107, 1377-1391. doi: $10.1111 / 1365-2745.13135$

Webber, B. L., Moog, J., Curtis, A. S., and Woodrow, I. E. (2007). The diversity of ant-plant interactions in the rainforest understorey tree, Ryparosa (Achariaceae): food bodies, domatia, prostomata, and hemipteran trophobionts. Bot. J. Linnean Soc. 154, 353-371. doi: 10.1111/j.1095-8339.2007. 00651.x

Weberling, F. (1981). Morphologie der Blüten und der Blütenstände. Stuttgart: Eugen Ulmer, doi: 10.1002/fedr.4910940614

Weidenmüller, A., Mayr, C., Kleineidam, C. J., and Roces, F. (2009). Preimaginal and adult experience modulates the thermal response behavior of ants. Curr. Biol. 19, 1897-1902. doi: 10.1016/j.cub.2009.08.059

Weryszko-Chmielewska, E., and Chwil, M. (2016). Flowering biology and structure of floral nectaries in Galanthus nivalis L. Acta Soc. Bot. Pol. 85, 1-20. doi: 10.5586/asbp. 3486 
Yamamoto, M., and Del-Claro, K. (2008). Natural history and foraging behavior of the carpenter ant Camponotus sericeiventris Guérin, 1838 (Formicinae, Campotonini) in the Brazilian tropical savanna. Acta Ethol. 11, 55-65. doi: 10.1007/s10211-008-0041-6

Young, A. M., and Hermann, H. R. (1980). Notes on foraging of the giant tropical ant Paraponera clavata (Hymenoptera: Formicidae: Ponerinae). J. Kansas Entomol. Soc. 53, 35-55.

Zhu, Y. R., Yang, M., Vamosi, J. C., Armbruster, W. S., Wan, T., and Gong, Y. B. (2017). Feeding the enemy: loss of nectar and nectaries to herbivores reduces tepal damage and increases pollinator attraction in Iris bulleyana. Biol. Lett. 13:20170271. doi: 10.1098/rsbl.2017.0271
Conflict of Interest: The authors declare that the research was conducted in the absence of any commercial or financial relationships that could be construed as a potential conflict of interest.

Copyright (C) 2020 Mesquita-Neto, Paiva, Galetto and Schlindwein. This is an openaccess article distributed under the terms of the Creative Commons Attribution License (CC BY). The use, distribution or reproduction in other forums is permitted, provided the original author(s) and the copyright owner(s) are credited and that the original publication in this journal is cited, in accordance with accepted academic practice. No use, distribution or reproduction is permitted which does not comply with these terms. 